\title{
SOIL INOCULUM POTENTIAL AND ARBUSCULAR MYCORRHIZAL COLONIZATION OF ACER RUBRUM IN FORESTED AND DEVELOPED LANDSCAPES
}

\author{
By P. Eric Wiseman ${ }^{1}$ and Christina Wells ${ }^{2}$
}

\begin{abstract}
Arbuscular mycorrhizal fungi (AMF) form a symbiotic relationship with numerous landscape tree species and can improve tree growth and environmental stress tolerance. Constructionrelated soil disturbance is thought to diminish AMF colonization of transplanted trees in newly developed landscapes. We gathered root, soil, and foliar data from red maples (Acer rubrum) growing in newly developed landscape sites and adjacent native forest sites to test two independent hypotheses: (1) landscape trees show lower levels of AMF colonization than forest trees, and (2) the AMF inoculum potential of landscape soils is lower than that of forest soils. Fine roots sampled from landscape maples had significantly lower AMF colonization than maples from adjacent forest sites (3\% versus $22 \%$ ). However, soil-sand mixtures made from landscape soils possessed greater AMF inoculum potential than those made from forest soils ( $10 \%$ versus $4 \%$ ). Forest soils were more acidic and possessed less extractable P than landscape soils, and differences in AMF colonization between field and landscape maples appeared to reflect differences in soil chemical properties rather than in inoculum potential. The results of this study suggest that not all disturbed landscape soils are deficient in AMF propagules.

Key Words. Acer rubrum; arbuscular mycorrhizal fungi; mycorrhizae; red maple; soil acidity; soil disturbance.
\end{abstract}

Arbuscular mycorrhizal fungi (AMF) form a symbiotic relationship with the fine roots of many landscape tree species. Numerous plant benefits have been attributed to the AMF symbiosis, including enhanced nutrient uptake, increased resistance to soilborne pests, greater heavy metal tolerance, and improved soil-water relations (Smith and Read 1997). Consequently, AMF colonization has the potential to improve the survival, growth, and appearance of landscape trees.

Landscape soils are frequently disturbed during land development and construction activities. Soil grading typically removes native vegetation and displaces biologically active topsoil. As a result, natural sources of AMF propagules (colonized roots, fungal spores, and fungal hyphae) in the soil are thought to be diminished. Disturbance of native soils by agricultural and surface mining activities has been shown to reduce AMF propagule abundance and infectivity (Jasper et al. 1989, 1991; Boerner et al. 1996; Gould et al. 1996). Less is known about the effect of soil disturbance on AMF activity in urbanized landscapes. In the southwestern United States, recently developed landscapes had lower AMF species diversity than landscapes developed 20 to 40 years earlier (Stutz and Martin 1998), and native desert trees had greater AMF colonization than their counterparts in residential landscapes (Stabler et al. 2001). Comparable research has not been performed in the temperate regions of the eastern United States.

Commercial inoculants containing AMF propagules are available for enhancing the AMF colonization of trees transplanted into disturbed landscape soils. While ectomycorrhizal inoculation has proven effective in promoting conifer survival and growth on disturbed sites (e.g., Marx et al. 1989; Marx 1991), AMF inoculation often fails to provide measurable benefits to landscape trees (e.g., Morrison et al. 1993; Martin and Stutz 1994; Appleton et al. 2003). The absence of an AMF inoculation effect may be related to high levels of soil fertility, adequate pre-treatment soil inoculum potentials, or sufficient pre-treatment levels of AMF colonization in the treated trees (Findlay and Kendle 2001). These issues have rarely been addressed in arboricultural research, and information on soil inoculum potential and tree colonization status may therefore prove helpful to arborists considering the use of AMF inoculants.

The overall objective of this study was to test the assertion that disturbed landscape soils are deficient in AMF propagules and do not promote the colonization of transplanted trees. Specifically, the objectives were (1) to compare AMF colonization of red maples (Acer rubrum) from native forest locations with that of red maples from nearby developed landscapes, (2) to compare AMF inoculum potential of native forest soil with that of soil from nearby developed landscapes, and (3) to evaluate relationships between AMF colonization and soil chemical properties at both locations.

\section{MATERIALS AND METHODS}

This investigation consisted of an observational field study and a greenhouse bioassay experiment. The field study was conducted in the upper South Carolina Piedmont of the United States in June 2004. Nine commercial/retail establishments were selected for observation based on two 
criteria: (1) presence of recently transplanted red maples in the landscape, and (2) proximity to a native forest containing red maples. Red maple was chosen for observation due to its prevalence in both native forests and urban landscapes and its capacity to form AMF symbioses.

Native soils of the upper South Carolina Piedmont are ultisols of the Cecil series. Their taxonomic class is fine, kaolinitic, thermic Typic Kanhapludults (Soil Survey Staff 2005). Forested sites typically possess a thin $(0$ to $8 \mathrm{~cm}$ [0 to 3 in.]) organic horizon composed of partially decayed leaves and twigs. Upper mineral horizons are designated A, E, BE, and Bt1 to a depth of $71 \mathrm{~cm}$ (28 in.). This horizonation may be truncated due to erosion from past agricultural use, and one or more of the surface horizons may be absent. The A and B horizons are typically sandy loam, clay loam, or clay, and are moderately to very strongly acid.

All of the commercial landscapes in our study had been established within the previous 3 years. The trees were typically established in highly disturbed native soil that had been graded and compacted to meet landscape design requirements. The surface soil was typically clay, and all trees possessed organic mulch rings to the drip line or beyond. The landscape maples had been balled and burlapped prior to transplant and were situated in parking lot islands or lawns near parking lot perimeters. Supplemental irrigation was present on some sites, but there was no known history of fertilizer or pesticide application to the trees. The average stem diameter of the landscape maples was $8.06 \pm 0.79 \mathrm{~cm}$ (3.17 $\pm 0.31 \mathrm{in}$.) at the time of observation.

The adjacent forest sites were typical midsuccessional mesic forests of the upper Piedmont. The overstory generally consisted of white oak (Quercus alba), tulip poplar (Liriodendron tulipifera), and pignut hickory (Carya glabra). Flowering dogwood (Cornus florida), sweetgum (Liquidambar styraciflua), and red maple were common in the understory and midstory. White oak and hickory species are ectomycorrhizal (Brundrett et al. 1990), while tulip poplar, sweetgum, flowering dogwood, and red maple form AMF symbioses (Simmons and Pope 1988; Klingeman et al. 2002). The surface soil at the forest sites was clay or clay loam and was covered with a thin duff mull litter layer.

Each of the 18 sampling locations (nine paired landscape and forested locations) constituted an experimental unit within a randomized complete block design. Each commer$\mathrm{cial} /$ retail establishment with its associated forested area constituted a block. Three maples were randomly selected as subsamples within each of the 18 experimental units. From each tree, fine roots were collected for AMF colonization measurement, soil was collected for chemical analysis and AMF inoculum potential measurement, and foliage was collected for tissue nutrient concentration measurement.

For the landscape maples, mulch and surface soil were raked away from the root zone to permit identification of the root ball/bulk soil interface. To sample fine roots that had been produced after transplanting, three $20 \mathrm{~cm}$ (8 in.) deep soil cores were removed just outside the root ball at a 30 to $40 \mathrm{~cm}$ (12 to $16 \mathrm{in}$.) distance from the stem base. Cores were located 120 degrees apart around the root ball circumference. Three soil cores per tree were combined in a plastic bag and stored in a cooler. Approximately $100 \mathrm{~g}$ (3.5 oz) of young, fully expanded leaves were collected from the crown of each tree and stored in paper bags.

At each forested location, three understory or midstory red maples were randomly selected as subsamples. Around the base of each tree, the litter layer was raked away to expose the mineral topsoil. To ensure that only red maple roots were collected, several lateral roots on each maple were manually excavated and approximately $2 \mathrm{~g}(0.07 \mathrm{oz})$ of live fine roots were harvested and stored in a cooler. Three $20 \mathrm{~cm}$ (8 in.) deep soil cores were collected around the circumference of each tree at a distance of about $30 \mathrm{~cm}$ (12 in.) from the stem base, combined in a plastic bag, and stored in a cooler. Foliage was sampled as in the landscape trees.

Foliar samples were immediately oven-dried at $70^{\circ} \mathrm{C}$ $\left(158^{\circ} \mathrm{F}\right)$ and submitted to the Clemson University Agriculture Service Laboratory for nutrient analysis. Root and soil samples were stored at $5^{\circ} \mathrm{C}\left(41^{\circ} \mathrm{F}\right)$ for less than 1 week before processing.

Individual soil samples were passed through a $0.5 \mathrm{~cm}$ (0.2 in.) sieve to remove rock fragments and coarse woody debris. Coarse roots captured on the sieve were cut into 1 $\mathrm{cm}$ (2.5 in.) fragments and returned to the sieved soil. A 500 $\mathrm{mL}(17 \mathrm{fl} \mathrm{oz}$ ) aliquot from each sieved soil sample was submitted to the Clemson University Agriculture Service Laboratory for nutrient analysis. The remaining sieved soil was returned to cold storage for 1 week prior to commencing the greenhouse bioassay.

Two grams $(0.07 \mathrm{oz})$ of maple fine roots were removed from each landscape soil sample prior to sieving and stored at $5^{\circ} \mathrm{C}\left(41^{\circ} \mathrm{F}\right)$ in $50 \%$ ethanol. Forest maple fine roots were also stored in ethanol. Fine root samples were prepared for AMF assessment by rinsing with distilled water, clearing with $10 \% \mathrm{KOH}$ for 6 to $12 \mathrm{~h}$ at $75^{\circ} \mathrm{C}\left(167^{\circ} \mathrm{F}\right)$, staining with trypan blue for $30 \mathrm{~min}$ at $75^{\circ} \mathrm{C}\left(167^{\circ} \mathrm{F}\right)$, and de-staining in $50 \%$ glycerol (Koske and Gemma 1989). AMF colonization was assessed using the magnified intersections method (McGonigle et al. 1990). For each sample, fifty $1 \mathrm{~cm}$ (0.4 in.) root segments were mounted on a glass slide and observed under 110x magnification using a compound microscope equipped with an cross-hair eyepiece. At a single intersection between each root segment and the eyepiece cross-hair, the presence/absence of AMF hyphae was noted. AMF colonization was then calculated as the percentage of the 50 root segment intersections at which hyphae were present.

A greenhouse bioassay was conducted to assess the AMF inoculum potential of soil from the landscape and forest 
sites. Each sieved soil sample was thoroughly mixed with steam-pasteurized sand in a 1:3 v/v ratio to improve soil mixture drainage and aeration (Richter et al. 2002). Two 164 $\mathrm{mL}(5.5 \mathrm{fl} \mathrm{oz})$ containers $(3.8 \times 21 \mathrm{~cm}[1.5 \times 8.3 \mathrm{in}$.$] ; Ray$ Leach Conetainer, Stuewe and Sons, Inc., Corvallis, OR) were filled with the soil/sand mixture prepared for each sample, and a single fungicide-free corn seed (Zea mays 'Viking', Albert Lea Seedhouse, Albert Lea, MN) was sown in each container. Seven control corn seeds were sown in containers with steam-pasteurized sand only. The 108 observational units ( 18 sites $\times 3$ subsamples $\times 2$ corn plants) along with the controls were completely randomized on a greenhouse bench. The plants were watered as needed and maintained under $16 \mathrm{~h}$ photoperiod. After 4 weeks of growth, the corn plants were destructively harvested. Shoots were oven-dried and weighed, and fine roots were assessed for AMF colonization as described above.

All statistical analyses were performed using SAS version 8.0 (SAS Institute, Cary, NC). In both the observational field study and greenhouse bioassay experiment, dependent variables were subjected to analysis of variance using a randomized complete block with subsampling error control design. The relatedness of soil, root, and foliar variables was evaluated using the Pearson Product Moment Correlation (PROC CORR). Pearson correlation coefficients range between +1 (perfect positive relationship) and -1 (perfect negative relationship), and the associated $p$-value is the probability that a coefficient equals zero (no relationship).

\section{RESULTS}

AMF colonization of fine roots was significantly greater in forest red maples than in landscape red maples $(P=0.0002$; Figure 1). On average, AMF hyphae were observed in $22 \%$ of fine root segments from forest maples versus 3\% of those from landscape maples.

In the greenhouse bioassay, AMF hyphal colonization of fine roots was significantly greater in corn plants grown in landscape soil mixtures than in plants grown in forest soil mixtures ( $P=0.0081$; Figure 1$)$. On average, AMF hyphae were observed in about $10 \%$ of corn fine root segments from landscape soil mixtures versus 4\% from forest soil mixtures. There was no significant difference in the shoot dry weights of corn plants from the two soil mixture types (data not shown). No AMF hyphae were observed in the fine roots of corn plants grown in steampasteurized control soil.

Twelve soil chemical properties were quantified for red maple rhizosphere soil collected at the forest and landscape sites (Table 1). Highly significant differences $(P<$ 0.01) were detected between the two site types for soil $\mathrm{pH}$ and soil acidity (a measure of both active and reserve acidity). On average, forest soils ( $\mathrm{pH}$ range 4.5 to 5.3) were more acidic than landscape soils ( $\mathrm{pH}$ range 4.9 to 7.0 ).

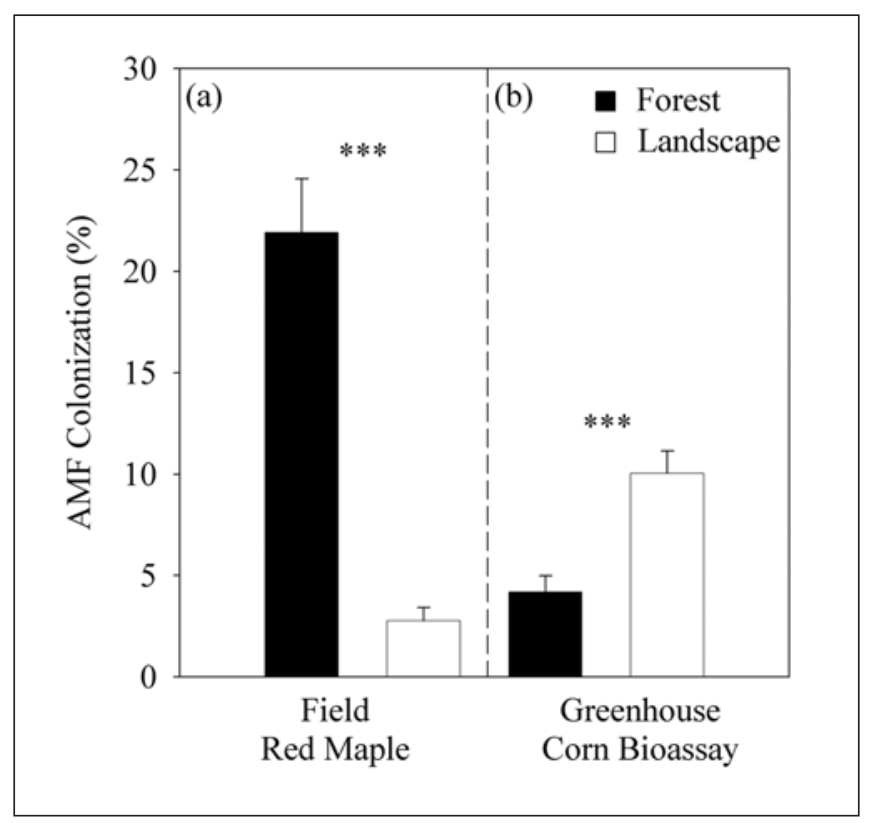

Figure 1. AMF colonization observed (a) in red maple fine roots collected at forest and landscape sites, and (b) in corn fine roots grown in sand amended with soil from forest and landscape sites. Error bars depict standard error of the mean $(n=9) . * *$ Site type means significantly different $(P<0.01)$.

Extractable phosphorus was twice as high in landscape soils as in forest soils, but this difference was only marginally significant $(P=0.13)$. Extractable base cation concentrations ( $\mathrm{Ca}, \mathrm{Mg}$, and $\mathrm{K}$ ) were significantly higher in landscape soils. There was no significant difference in soil $\mathrm{NO}_{3}-\mathrm{N}$ levels between the two sites.

Foliar levels of ten nutrients were quantified for forest red maples and landscape red maples (Table 2). Foliar N, Ca,

Table 1. Chemical properties of soil collected from native forest and landscape sites. Standard errors of the means are shown in parentheses $(n=9)$. Asterisks denote statistical significance of differences in site type means for each soil property.

\begin{tabular}{lclrl}
\hline Property & \multicolumn{2}{c}{ Forest } & \multicolumn{2}{c}{ Landscape } \\
\hline $\mathrm{pH}$ & 4.9 & $(0.1)$ & 5.6 & $(0.1)^{* * *}$ \\
$\mathrm{NO}_{3}-\mathrm{N}(\mathrm{ppm})$ & 1.50 & $(0.20)$ & 2.60 & $(0.69)$ \\
$\mathrm{K}(\mathrm{ppm})$ & 40.60 & $(5.80)$ & 55.80 & $(2.87)^{*}$ \\
$\mathrm{Ca}(\mathrm{ppm})$ & 97.50 & $(7.44)$ & 258.80 & $(41.65)^{* *}$ \\
$\mathrm{Mg}(\mathrm{ppm})$ & 23.70 & $(2.70)$ & 47.00 & $(5.93)^{* *}$ \\
$\mathrm{Zn}(\mathrm{ppm})$ & 1.10 & $(0.16)$ & 2.30 & $(0.67)$ \\
$\mathrm{Mn}(\mathrm{ppm})$ & 9.10 & $(1.10)$ & 12.50 & $(1.36)$ \\
$\mathrm{Cu}(\mathrm{ppm})$ & 0.56 & $(0.06)$ & 0.82 & $(0.09)^{* *}$ \\
$\mathrm{~B}(\mathrm{ppm})$ & 0.20 & $(0.02)$ & 0.15 & $(0.01)^{*}$ \\
$\mathrm{CEC}(\mathrm{meq} / \mathrm{l00} \mathrm{g})$ & 5.70 & $(0.24)$ & 4.50 & $(0.24)^{* *}$ \\
Acidity $(\mathrm{meq} / \mathrm{l00} \mathrm{g})$ & 4.80 & $(0.22)$ & 2.40 & $(0.20)^{* * *}$ \\
\hline
\end{tabular}

***P<0.01; ** $P<0.05 ; * P<0.1$ 
and Mn concentrations were significantly greater in forest red maples. Based on foliar nutrient sufficiency ranges for maple species (A\&L Eastern Agricultural Laboratories, Inc., Richmond, VA), both forest and landscape red maples were deficient in $\mathrm{P}, \mathrm{Ca}, \mathrm{Mg}$, and S. Landscape red maples were slightly deficient in foliar N. Foliar Mn levels exceeded the sufficiency range on average in both forest and landscape red maples.

Results of the Pearson correlation analysis are presented in Table 3. When data from all sites and trees were combined, there was no significant relationship between maple AMF colonization and bioassay AMF colonization $(P=$ 0.8978). However, maple AMF colonization was negatively correlated with soil $\mathrm{pH}$ and positively correlated with CEC and soil acidity $(P<0.01)$. In other words, AMF colonization levels were higher on more acidic soils.

There was a marginally significant negative relationship between foliar P content and maple AMF colonization $(P<$ 0.1 ) but no significant relationship between soil extractable $\mathrm{P}$ and colonization. However, extractable P levels do not necessarily reflect $\mathrm{P}$ availability to the plant, as $\mathrm{P}$ availability is strongly influenced by soil $\mathrm{pH}$.

Table 2. Foliar nutrient levels of red maples growing on forest and landscape sites. Standard errors of the means are shown in parentheses $(n=9)$. Asterisks denote statistical significance of differences in site type means for each soil property.

\begin{tabular}{lrrrll}
\hline Nutrient & \multicolumn{2}{c}{ Forest } & \multicolumn{2}{c}{ Landscape } & Sufficiency $^{2}$ \\
\hline $\mathrm{N}(\%)$ & 1.74 & $(0.04)$ & 1.51 & $(0.06)^{* *}$ & $1.60-2.20$ \\
$\mathrm{P}(\%)$ & 0.12 & $(0.01)$ & 0.13 & $(0.01)$ & $0.18-0.30$ \\
$\mathrm{~K}(\%)$ & 0.85 & $(0.06)$ & 0.81 & $(0.04)$ & $0.50-0.80$ \\
$\mathrm{Ca}(\%)$ & 0.84 & $(0.05)$ & 0.71 & $(0.05)^{*}$ & $2.00-3.00$ \\
$\mathrm{Mg}(\%)$ & 0.21 & $(0.01)$ & 0.20 & $(0.01)$ & $0.26-0.40$ \\
$\mathrm{~S}(\%)$ & 0.11 & $(0.01)$ & 0.11 & $(0.01)$ & $0.17-0.30$ \\
$\mathrm{Zn}(\mathrm{ppm})$ & 35.10 & $(2.74)$ & 34.40 & $(2.01)$ & $20-50$ \\
$\mathrm{Mn}(\mathrm{ppm})$ & 1086.10 & $(122.51)$ & 816.90 & $(97.14)^{*}$ & $50-200$ \\
$\mathrm{Cu}(\mathrm{ppm})$ & 7.50 & $(0.46)$ & 8.10 & $(1.02)$ & $6-20$ \\
Fe (ppm) & 74.80 & $(4.81)$ & 110.60 & $(17.41)$ & $60-300$ \\
\hline
\end{tabular}

zSufficiency ranges provided by A\&L Eastern Agricultural Laboratories, Inc., Richmond, VA.

***P $<0.01 ; * * P<0.05 ; *<0.1$

Table 3. Correlations among red maple AMF colonization, corn bioassay colonization, soil chemical properties, and foliar P levels. Numerical values are Pearson correlation coefficients. Asterisks following coefficients denote statistical significance. Data from all trees at all sites are combined $(n=54)$.

\begin{tabular}{lllllll}
\hline & BAMFy & Soil pH & CEC & Soil acidity & Soil P & Foliar P \\
\hline MAMF $^{z}$ & -0.018 & $-0.418^{* * *}$ & $0.584^{* * *}$ & $0.637^{* * *}$ & -0.153 & $-0.229 *$ \\
\hline
\end{tabular}

${ }^{z}$ Maple AMF colonization.

'Bioassay AMF colonization.

${ }^{*} * P<0.01 ; * * P<0.05 ; * P<0.1$

\section{DISCUSSION}

AMF Hyphal Frequency in Forest and Landscape Maples

Our data support the hypothesis that red maples from native forests possess greater AMF colonization than those from recently developed landscapes (22\% vs. 3\%). This observation may reflect $\mathrm{pH}$-related differences in plantavailable P between the two site types. Although the site types did not differ significantly in extractable P, they did differ markedly in soil $\mathrm{pH}$. At low soil $\mathrm{pH}(<5.5)$, P forms insoluble precipitates with iron and aluminum, and phosphate ions are readily adsorbed to $\mathrm{Al} / \mathrm{Fe}$ oxides on the edges of clay colloids (Havlin et al. 1999). Both of these phenomena decrease P availability to the plant.

In acidic soils, AMF hyphae can improve scavenging of scarce solution $\mathrm{P}$ by growing into soil not occupied by roots and by accessing soil pores of smaller diameter than fine roots (Smith and Read 1997). The presence of AMF hyphae has also been associated with increased rhizosphere activity of acid and alkaline phosphatases, enzymes capable of mineralizing organic P (Feng et al. 2002). Finally, AMF hyphae are capable of sustaining high rates of phosphate influx: the $I_{\max }$ of the high affinity phosphate uptake system in AMF hyphae was calculated to be two orders of magnitude greater than that of roots (Smith et al. 2001).

Forest maples may have permitted greater levels of AMF colonization in response to acidityrelated $\mathrm{P}$ limitation, whereas landscape maples may have restricted the development of AMF colonization in response to higher soil $\mathrm{P}$ availability. Interestingly, foliar $\mathrm{P}$ levels in forest and landscape maples were low and nearly identical, suggesting that trees at the two locations derived similar outcomes from different $\mathrm{P}$ acquisition strategies.

There is little published research on typical levels of AMF colonization in forest-grown red maple. Brundrett et al. (1990) observed similarities in fine root and AMF anatomy between forest-grown red maple and sugar maple (Acer saccharum) and noted that red maple typically possessed lower levels of AMF colonization. In northern deciduous forests of the United States and Canada, sugar maple AMF hyphal frequencies of $9 \%$ to $60 \%$ have been reported (Brundrett and Kendrick 1988; Klironomos et al. 1993; Zahka et al. 1995; Coughlan et al. 2000). Red maple seedlings transplanted to a mid-Atlantic deciduous forest exhibited AMF hyphal frequencies of $19 \%$ to $37 \%$ across a range of landforms and canopy densities (Lovelock and Miller 2002). 
Our observation of 22\% mean AMF hyphal frequency for forest red maple growing on clay and clay-loam soils is within the range of values reported in these studies.

There are also few published estimates of AMF colonization in nursery-grown and/or transplanted maples. Mean AMF hyphal frequencies of 29\% to 52\% were reported for red maples growing in undisturbed loam soil at a selection of Tennessee nurseries (Klingeman et al. 2002). Posttransplant AMF hyphal frequencies of 9\% to 17\% were reported in a variety of maple species (Morrison et al. 1993; Appleton et al. 2003; Wiseman, unpublished data). Our observation of 3\% AMF hyphal frequency in landscape red maples is lower than previously reported values for transplanted maples, but differences in plant material and soil type limit comparisons with previous work.

\section{AMF Inoculum Potential of Forest and Landscape Soils}

The results of the greenhouse bioassay did not support the hypothesis that AMF inoculum potential is greater in native forest soil than in developed landscape soil. The inoculum potential of landscape soil mixtures was more than twice that of forest soil mixtures. This result was unexpected given that forest maples possessed greater AMF colonization than landscape maples. A number of factors may have contributed to this result.

First, fine root length densities of soil cores from the landscape sites were higher than those of soil cores from the forest sites (Wiseman, personal observation). As a consequence, bioassay soil mixtures created from the landscape soils contained more root material than mixtures created from the forest soils. AMF-colonized fine roots are a significant source of inoculum. Higher root length densities may have enhanced the inoculum potential of the landscape soil mixtures, despite the fact that hyphal frequency was lower in landscape roots.

Second, it has been amply demonstrated that the extent of root colonization decreases as soil P availability increases in a variety of soils and plant species (Smith and Read 1997). Maples may have been actively limiting the extent of their mycorrhizal colonization in response to higher P availability on the landscape sites. In this case, it is not surprising that colonization correlated poorly with soil inoculum potential.

Third, soil from the developed sites was collected up to three years after landscape installation. It may be that the landscape soils were initially deficient in AMF propagules, but that inoculum potential recovered through time. Evidence suggests that AMF inoculum potential can be quite resilient in the face of significant soil disturbance: the AMF propagule density and colonization of herbaceous cover crops recovered within 2 years after reclamation of Kentucky surface mine sites (Gould et al. 1996). In a separate study, $98 \%$ of the sampling points in an artificial strip-mine site possessed enough AMF propagules to establish colonization in AMF-dependent species (Boerner et al. 1996).

Finally, we cannot exclude the possibility that AMF species present in the landscape sites were more readily able to colonize corn, the greenhouse bioassay plant, than those from the forest sites. While most AMF species have a remarkably broad host range, it is possible that landscape inoculum was enriched in species that colonized turfgrass from nearby lawns and was therefore more likely to infect closely related corn than distantly related red maple. It is interesting to note, however, that many commercial AMF inoculants are also prepared using monocot host plants such as sudangrass and sorghum.

\section{CONCLUSION}

Although forest red maples were more extensively colonized than landscape maples, the AMF inoculum potential of forest soils was actually lower than that of landscape soils. The extent of red maple AMF colonization was not related to soil inoculum potential but instead was strongly correlated with soil $\mathrm{pH}$. We suggest that red maple may permit greater AMF colonization in response to low $\mathrm{P}$ availability on acidic soils.

The results reported here do not support the assertion that all developed landscape soils require amendment with commercial AMF inoculants. While the landscape soils in our study may have experienced a transient decline in inoculum potential following disturbance, AMF populations appear to have reestablished rapidly. It is possible that other types of disturbed landscapes - particularly those treated with soil fumigants such as methyl bromide - may benefit from artificial inoculation to enhance degraded AMF populations. Much more data on the quantity and quality of AMF propagules in a variety of landscape soils is needed before arborists can adequately evaluate the necessity of AMF inoculation.

\section{LITERATURE CITED}

Appleton, B., J. Koci, S. French, M. Lestyan, and R. Harris. 2003. Mycorrhizal fungal inoculation of established street trees. J. Arboric. 29(2):107-110.

Boerner, R.E., B.G. DeMars, and P.N. Leicht. 1996. Spatial patterns of mycorrhizal infectiveness of soils long a successional chronosequence. Mycorrhiza 6:79-90.

Brundrett, M.C., and B. Kendrick. 1988. The mycorrhizal status, root anatomy, and phenology of plants in a sugar maple forest. Can. J. Bot. 66:1153-1173.

Brundrett, M., G. Murase, and B. Kendrick. 1990. Comparative anatomy of roots and mycorrhizae of common Ontario trees. Can. J. Bot. 68:551-578.

Coughlan, A.P., Y. Dalpé, L. Lapointe, and Yves Piché. 2000. Soil pH-induced changes in root colonization, diversity, and reproduction of symbiotic arbuscular mycorrhizal 
fungi from healthy and declining maple forests. Can. J. For. Res. 30:1543-1554.

Feng, G., Y. Su, X. Li, H. Wang, F. Zhang, C. Tang, Z. Rengel. 2002. Histochemical visualization of phosphatase released by arbuscular mycorrhizal fungi in soil. J. Plant Nutr. 25(5):969-980.

Findlay, C.M., and A.D. Kendle. 2001. Towards a mycorrhizal application decision model for landscape management. Landsc. Urban Plann. 56:149-160.

Gould, A.B., J.W. Hendrix, and R.S. Ferriss. 1996. Relationship of mycorrhizal activity to time following reclamation of surface mine land in western Kentucky. I. Propagule and spore population densities. Can. J. Bot. 74:247-261.

Havlin, J.L., J.D. Beaton, S.L. Tisdale, and W.L. Nelson. 1999. Soil Fertility and Fertilizers: An Introduction to Nutrient Management. Prentice-Hall, Upper Saddle River, NJ. 499 pp.

Jasper, D.A., L.K. Abbott, and A.D. Robson. 1989. Soil disturbance reduces the infectivity of external hyphae of vesicular-arbuscular mycorrhizal fungi. New Phytol. 112:93-99.

- 1991. The effect of soil disturbance on vesiculararbuscular mycorrhizal fungi in soils from different vegetation types. New Phytol. 118:471-476.

Klingeman, W.E., R.M. Augé, and P.C. Flanagan. 2002. Arbuscular mycorrhizal assessment of ornamental trees grown in Tennessee field soils. HortScience 37(5):778-782.

Klironomos, J.N, P. Moutoglis, B. Kendrick, and P. Widden. 1993. A comparison of spatial heterogeneity of vesiculararbuscular mycorrhizal fungi in two maple-forest soils. Can. J. Bot. 71:1472-1480.

Koske, R.E., and J.N. Gemma. 1989. A modified procedure for staining roots to detect VA mycorrhizas. Mycol. Res. 92(4):486-505.

Lovelock, C.E., and R. Miller. 2002. Heterogeneity in inoculum potential and effectiveness of arbuscular mycorrhizal fungi. Ecology 83(3):823-832.

Martin, C.A., and J.C. Stutz. 1994. Growth of Argentine mesquite inoculated with vesicular-arbuscular mycorrhizal fungi. J. Arboric. 20:134-138.

Marx, D.H. 1991. The practical significance of ectomycorrhizae in forest establishment, pp. 54-90. In Ecophysiology of Ectomycorrhizae of Forest Trees. Marcus Wallenberg Foundation Symposia Proceedings, Vol. 7. M. Wallenberg Foundation, Stockholm, Sweden.

Marx, D.H., S.B. Maul, and C.E. Cordell. 1989. Application of specific ectomycorrhizal fungi in world forestry, pp. 7898. In Frontiers in Industrial Mycology. American Mycological Society, Chapman and Hall, New York, NY.

McGonigle, T.P., M.H. Miller, D.G. Evans, G.L. Fairchild, and J.A. Swan. 1990. A new method which gives an objective measure of colonization of roots by vesicular-arbuscular mycorrhizal fungi. New Phytol. 115:495-501.
Morrison, S.J., P.A. Nicholl, and P.R. Hicklenton. 1993. VA mycorrhizal inoculation of landscape trees and shrubs growing under high fertility conditions. J. Environ. Hortic. 11(2):64-71.

Richter, B.S., R.L. Tiller, and J.C. Stutz. 2002. Assessment of arbuscular mycorrhizal fungal propagules and colonization from abandoned agricultural fields and semi-arid grasslands in riparian floodplains. Appl. Soil Ecol. 20:227-238.

Simmons, G.L., and P.E. Pope. 1988. Influence of soil water potential and mycorrhizal colonization on root growth of yellow-poplar and sweet gum seedlings grown in compacted soil. Can. J. For. Res. 18:1392-1396.

Smith, S.E., and D.J. Read. 1997. Mycorrhizal Symbiosis. Academic Press, San Diego, CA. 605 pp.

Smith, S.E., S. Dickson, and F.A. Smith. 2001. Nutrient transfer in arbuscular mycorrhizas: How are fungal and plant processes integrated? Aust. J. Plant Physiol. 28:683-694.

Soil Survey Staff, Natural Resources Conservation Service, United States Department of Agriculture. 2005. Official Soil Series Descriptions. http://soils.usda.gov/soils/ technical/classification/osd/index.html (accessed 1/20/05).

Stabler, L.B., C.A. Martin, and J.C. Stutz. 2001. Effect of urban expansion on arbuscular mycorrhizal fungal mediation of landscape tree growth. J. Arboric. 27(4):193-201.

Stutz, J.C., and C.A. Martin. 1998. Arbuscular mycorrhizal fungal diversity associated with ash trees in urban landscapes in Arizona. Phytopathology 88(9):S86.

Zahka, G.A., K.L. Baggett, and B.L. Wong. 1995. Inoculum potential and other VAM fungi parameters in four sugar maple forests with different levels of stand dieback. For. Ecol. Manage. 75:123-134.

Acknowledgments. The authors gratefully acknowledge the support of the Tree Research and Education Endowment Fund. Kristen Colvin and Erin Mostoller provided invaluable assistance with field sampling and microscopy work.

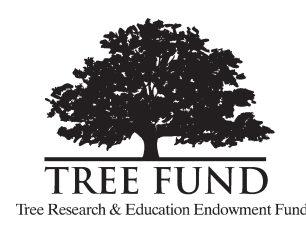

${ }^{1}$ Graduate Student

Department of Forestry and Natural Resources

Clemson University

Clemson, SC 29634-0317, U.S.

$2^{2 *}$ Assistant Professor

Department of Horticulture

Clemson University

Clemson, SC 29634-0319, U.S.

*Corresponding author. 
Résumé. Les champignons de mycorhizes arbusculaires (CMA) forment une relation symbiotique avec plusieurs espèces d'arbres ornementales et peuvent améliorer la croissance de l'arbre et sa tolérance à des stress environnementaux. Les sols perturbés suite à des travaux de construction sont réputés diminuer la colonisation par les CMA dans le cas d'arbres plantés au sein d'aménagements paysagers dans les nouveaux développements. Nous avons récolté des données sur les racines, les feuilles et le sol à partir d'érables rouges ornementaux (Acer rubrum) poussant dans ce type de site et aussi à partir de sites adjacents à des forêts naturelles afin de vérifier deux hypothèses indépendantes: 1) les arbres ornementaux ont des taux moindre de mycorhization que les arbres forestiers, et 2) le potentiel d'inoculation par les CMA au sein de sols d'aménagement paysager est moindre que celui de sols forestiers. Les fines radicelles échantillonnées à partir d'érables ornementaux avaient une colonisation moindre par les CMA que les érables dans les sites forestiers adjacents (3\% versus 22\%). Cependant, les mélanges de sol utilisés pour les arbres ornementaux possédaient un potentiel d'inoculation par les CMA plus grand que celui des sols forestiers ( $10 \%$ versus $4 \%$ ). Les sols forestiers étaient plus acide et possédaient moins de phosphore disponible que les sols utilisés pour les arbres ornementaux, et les différences dans la colonisation par les CMA, et ce entre les érables naturels et ceux ornementaux, apparaissaient se refléter dans les différences au niveau des propriétés chimiques du sol plus que dans le potentiel d'inoculation. Les résultats de cette étude suggèrent que ce ne sont pas tous les sols perturbés utilisés en aménagement paysager dont qui sont déficients en propagules de CMA.

Zusammenfassung. AMF formen eine symbiotische Beziehung mit zahlreichen Baumarten und verbessern die Stresstoleranz und Wachstumrate. Baubedingte Bodenstörungen werden als Ursache für verminderte AMF-Kolonisationen von verpflanzten Bäumen in neu gestalteten Landschaften gesehen. Wir sammelten Wurzeln, Boden und Laubdaten von Acer rubrum an neuen und alten Standorten, um 2 unabhängige Hypothesen zu testen: 1. Landschaftsbäume zeigen weniger AMF-Kolonisation als
Waldbäume und 2. das AMF Inoculum-Potential von Landschaftsböden ist niedriger als bei Forstböden. Feine Wurzeln, die von Landschaftsbäumen gesammelt wurden, zeigten deutlich niedrigere AMF-Level als die Proben von benachbarten Forstbäumen (3\% versus 22\%). Dennoch besaßen die Sand-BodenGemische aus Landschaftsböden ein größeres AMF InoculumPotential als die Forstböden (10\% versus 4\%). Forstböden waren saurer und besaßen mehr extrahierbares $\mathrm{P}$ als Landschaftsböden und die Differenzen in AMF_Kolonisationen von Feld- und Landschaftsahornen schienen die Unterschiede in den Bodenchemischen Eigenschaften eher zu reflektieren als in dem Inoculations-Potential. Das Resultat dieser Studie deutet an, dass nicht alle gestörten Landschaftsböden an AMF mangeln.

Resumen. El hongo micorrízico arbuscular (AMF, por sus siglas en inglés) forma una relación simbiótica con numerosos árboles en arquitectura del paisaje y puede mejorar su crecimiento y la tolerancia al estrés ambiental. El disturbio relacionado con el suelo en las construcciones disminuye la colonización de AMF de árboles trasplantados en paisajes nuevos. Obtuvimos datos foliares, de raíz y de suelo de maples rojos (Acer rubrum) creciendo en desarrollos nuevos y de sitios nativos de bosques adyacentes, para probar dos hipótesis independientes: (1) los árboles de paisajes muestran niveles más bajos de colonización de AMF que los árboles de los bosques y (2) el potencial de inoculación de AMF de suelos en nuevos paisajes es más abajo que los de los suelos forestales. En las raíces finas muestreadas de los maples del paisaje, la colonización de AMF fue significativamente más baja que en los sitios forestales adyacentes (3\% versus 22\%). Sin embargo, las mezclas suelo-arena echas de los suelos del paisaje tenían mayores inóculos potenciales de AMF que las hechas de suelos forestales (10\% versus 4\%). Los suelos forestales fueron más ácidos y con menor $\mathrm{P}$ disponible que los suelos del paisaje, y las diferencias en colonización de AMF entre maples de campo y de paisaje pareció reflejar contrastes en propiedades químicas antes que en potencial de inoculación. Los resultados de este estudio sugieren que no todos los suelos del paisaje son deficientes en propágulos de AMF. 